\title{
Decentralized Management of Urban Wastewater for Rural Agricultural Utilization
}

\author{
Sahana B Gangal, S. Sanjana, Asham Husain, \\ K. Gajalakshmi
}

\begin{abstract}
In Bengaluru nearly 50\% of the wastewater is treated. But the utilization of the treated water is not accounted efficiently, and the quality is being questioned. The treated water is not acceptable for irrigation due to presence of heavy metals and water parameters (such TDS and BOD) in unacceptable range. As tertiary treatment is expensive, experts suggest an alternative of employing constructed wetlands. In an intensely occupied city like Bengaluru a decentralized system is necessary. Hence the study focuses on finding optimal location for constructing wetlands, on wastelands surrounding Bengaluru urban. Weighted overlay analysis is performed to find the optimal location based on parameters such as slope, soil texture and land use. The results obtained are optimal locations to construct wetlands and approximated calculation of output capacity.
\end{abstract}

Keywords--- Constructed Wetlands, Decentralized Approach to Wastewater Treatment, Wastewater Management, Geographical Information System (GIS).

\section{INTRODUCTION}

Reclaimed water or wastewater reuse is being regarded as a water-conserving measure. Wastewater reuse is an alternative which provides significant economic, social and environmental benefits. This sustainable measure has various applications, including utilization of reclaimed water for irrigation purposes, which has been a long-established practice in arid areas of the world. Irrigation with reclaimed water usually contributes to improve the production yields, reduce the ecological footprint and promote socio-economic benefits.

In Bengaluru city with rapid growing population, demand for water and production of wastewater is increasing rapidly which shows the necessity for recycle and reuse of wastewater to meet the water demand. In Bengaluru nearly 1443 MLD wastewater is generated, out of which around 760 MLD wastewater is treated daily, with the help of 24 BWSSB Sewage Treatment Plants (STP). Secondary treated water from Bengaluru is supplied to various lakes and irrigation tanks surrounding the city. But the quality of treated water for the use of irrigation is questionable. The treated water does not suffice quality parameters (lesser BOD, higher TDS than permissible limit) and presence of

\footnotetext{
Manuscript received September 16, 2019.

Sahana B Gangal, UG Student, Department of Civil Engineering, RV College of Engineering, Bengaluru. (e-mail: sahanabgangal@ gmail.com)

S. Sanjana, UG Student, Department of Civil Engineering, RV College of Engineering, Bengaluru. sanjanas. (e-mail: sanjanas.cv15@rvce.edu.in)

Asham Husain, UG Student, Department of Civil Engineering, RV College of Engineering, Bengaluru. (e-mail: ashamhusain96@gmail.com)

Dr.K. Gajalakshmi, Assistant Professor, Department of Civil Engineering, RV College of Engineering, Bengaluru. (e-mail: gajalakshmik@rvce.edu.in)
}

heavy metals. Studies have proved that the heavy metals present in the treated water being bio accumulated in the crops and vegetables grown on the downstream on these STP valley and is sold in the local markets of the city [1][2]. Therefore, the treated water cannot be supplied to lakes or can be used for irrigation purposes and the demand for purchase of treated water is still low. Since tertiary treatment is expensive, there is a major stress on alternative method of tertiary treatment and management of wastewater.

For this purpose, constructed wetlands (CW) are found to be beneficiary as they owe to lower operation cost and maintenance. Constructed wetlands are artificial biogeochemical treatment systems which have been successfully adopted in many countries [3]. Constructed wetlands are provided to meet strict TSS and BOD standards. An integrated system of $\mathrm{CW}$ is being used in Jakkur STP in Bengaluru and is successfully operating till date [4]. The objective of the study was to propose a cost effective, green and sustainable management solution of secondary treated water, suitable for irrigation purposes.

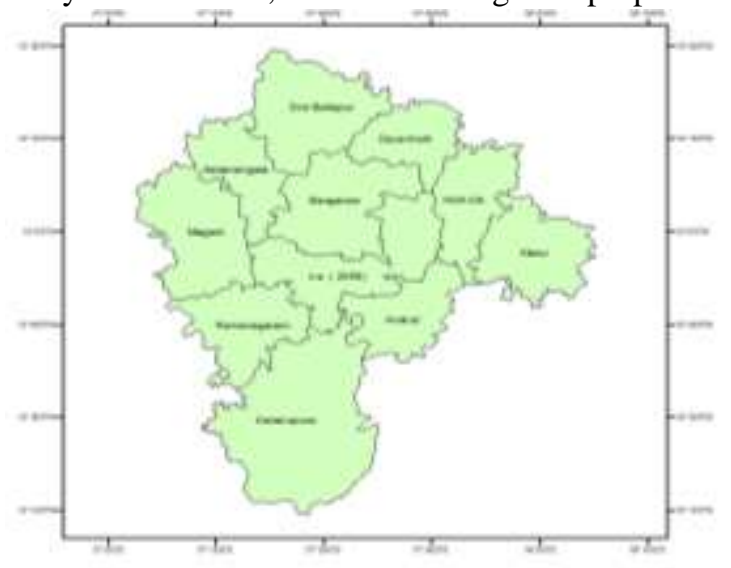

Figure 1: Study area

\section{STUDY AREA}

Study area comprises of Bengaluru urban district and surrounding rural taluks, namely Dodballapur, Devanahalli, Nelamangala, Magadi, Hoskote, Malur, Anekal, Kanakapura, Ramnagaram in Karnataka, India. It lies between $13^{\circ} 29^{\prime} 38.50^{\prime \prime}$ and $12^{\circ} 14^{\prime} 51.46^{\prime \prime}$ North latitude and between $77^{\circ} 26^{\prime} 2.94^{\prime \prime}$ and $77^{\circ} 22^{\prime} 24.582^{\prime \prime}$ East

longitude as shown in figure 1 . 


\section{DECENTRALIZED MANAGEMENT OF URBAN WASTEWATER FOR RURAL AGRICULTURAL UTILIZATION}

Average annual temperature of the region is $24.10^{\circ} \mathrm{C}$. Bengaluru urban has undergone rapid urbanization. A majority of $70 \%$ is covered with crop land, plantations and fallow land.

\section{METHODOLOGY}

The study aims at proposing the optimal location for CW in the areas neighboring Bengaluru urban. Sewage treatment plants (STPs) are identified in Bengaluru and water quality parameters of effluents from each STP are obtained. From the digital elevation model (DEM), slope map and stream flow map is generated using ArcGIS software. Weighted overlay analysis is performed using slope map, LULC map, soil texture map and soil depth characteristics map to obtain optimal location for CWs. Weighted overlay analysis is conducted using ArcGIS, where a numerical weightage is assigned to each parameter under consideration.

Waste lands are identified on the outskirts of the city using LULC map. Using results of weighted overlay analysis, identified wastelands and stream feature map an optimal location is considered for the construction of wetlands for treatment of the wastewater. Land study is done and suitable proposal for constructed wetlands in terms of area is calulated using equation 1 , plants grown, capacity of water that can be treated are proposed (figure 2).

$$
A=Q_{d} \frac{\ln \left(C_{i}\right)-\ln \left(C_{e}\right)}{K_{B O D}}
$$

$\mathrm{A}=$ Area of constructed wetland,

$\mathrm{Q}_{\mathrm{d}}$ average inflow in $\mathrm{m}^{3} /$ day,

$\mathrm{C}_{\mathrm{i}}$ and $\mathrm{C}_{\mathrm{e}}$ are influent and effluent $\mathrm{BOD}$ in milligrams per liter,

$\mathrm{K}_{\mathrm{BOD}}$ is a reaction constant of value 0.1 .

Effluent BOD is calculated by interpolating using this correlation: when influent raw sewage BOD is $60-80 \mathrm{mg} / \mathrm{L}$, the anticipated effluent BOD is $10 \mathrm{mg} / \mathrm{L}$ [4].

\section{DATA USED}

\section{Sewage Treatment Plants}

Working BWSSB sewage treatment plants in Bengaluru region area identified where the utilization of treated water is not satisfactory. Table 2 shows the details about the various STPs considered. STPs considered are: Raja canal, Nagasandra, Horamavu agara, Yellamapachetty, Bellandur, Mylasandra, Vrishabhavathi Valley, K\&C Valley, Chikkabanavara and Doddabele. Water quality parameters such as temperature, biodegradable oxygen, total suspended solids, $\mathrm{pH}$, chemical oxygen demand, dissolved oxygen are obtained from the real time monitoring data available on BWWSB website. Secondary treatment methods used in these STPs are extended aeration, trickle filters, sequencing batch reactor and activated sludge process. The capacity of the STPs vary from 5MLD to 248MLD.

\section{Land Use Land Cover Map}

LULC map depicts the various types of land coverage in the study area as shown in figure 3 . Most of the area is covered by crop land, plantations and fallow land for cultivation which shows higher requirement of water for irrigation. For constructed wetlands area under the land type wasteland, shrub land, permanent wetlands and barren land were considered as wastelands (suitable). For weighted overlay analysis land types were divided into five major categories, where wastelands category was given highest priority number and built-up area and water body was given lowest priority number.

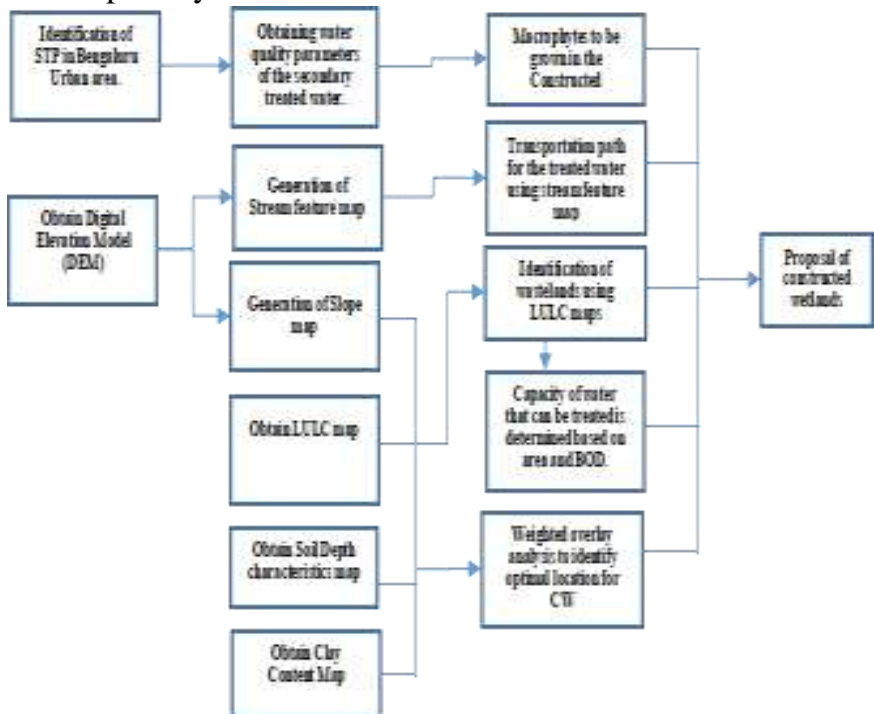

Figure 2: Methodology flow chart

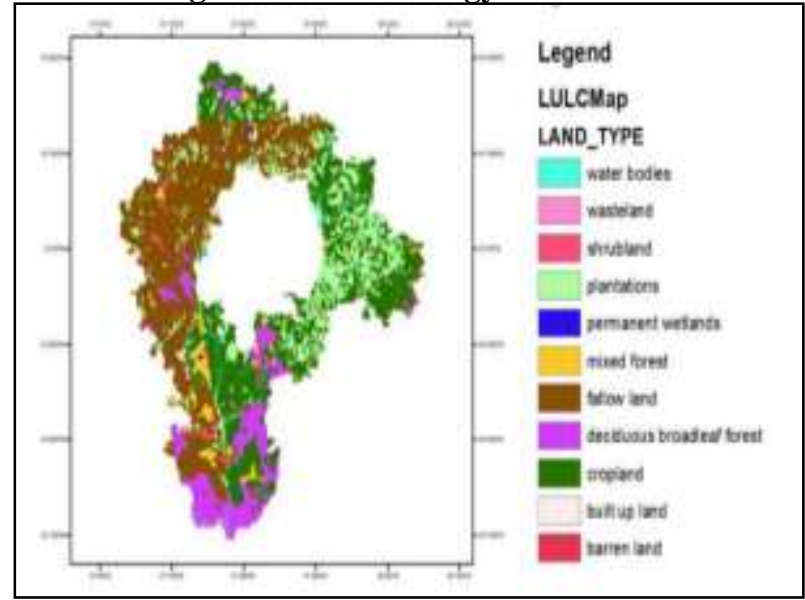

Figure 3: Land use Land cover map

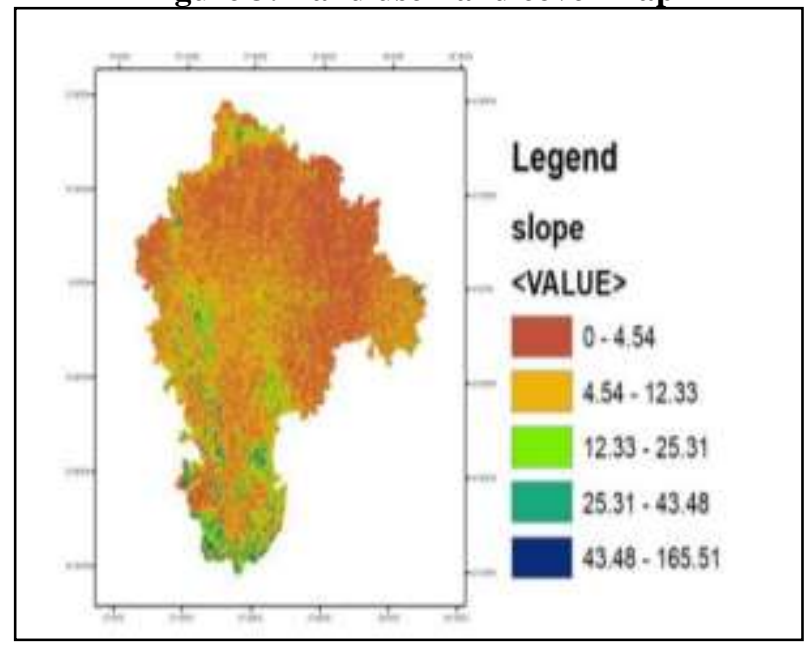

Figure 4: Slope map

Published By: 


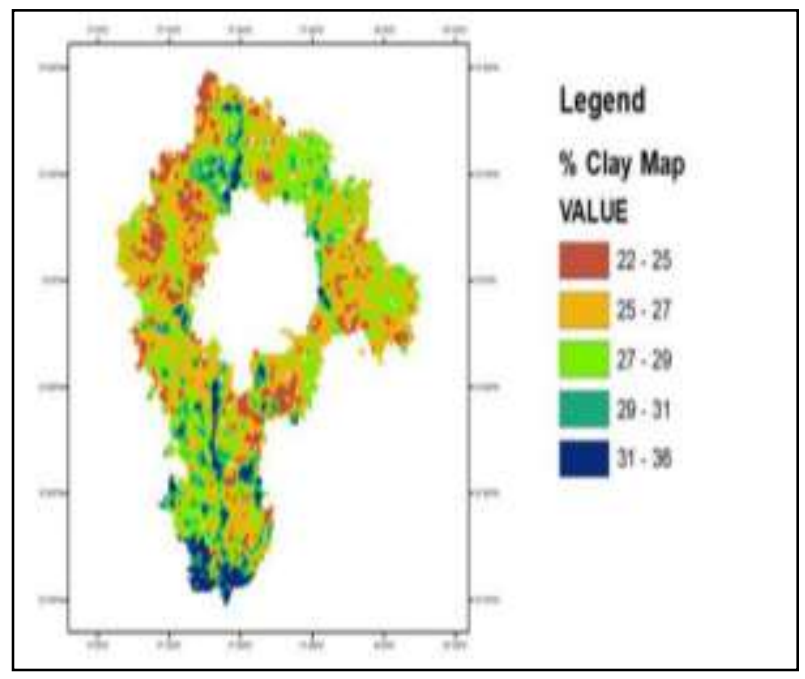

Figure 5: Soil Texture map

\section{Slope Map}

Slope Map is generated from digital elevation model (DEM) using spatial analysis tool, based on percentage rise as shown in figure 4. Slope map is classified as gently sloping, moderately sloping, moderately steep sloping, steep sloping and precipitous sloping. Here the classification is done based on natural breaks to group the similar values and maximize the difference between each class group. The slope map obtained showed that gentle sloping class covers highest area. In our study wastelands considered are at a lower slope than the STPs, hence higher slope is given lower priority number and lesser slope is given highest priority number.
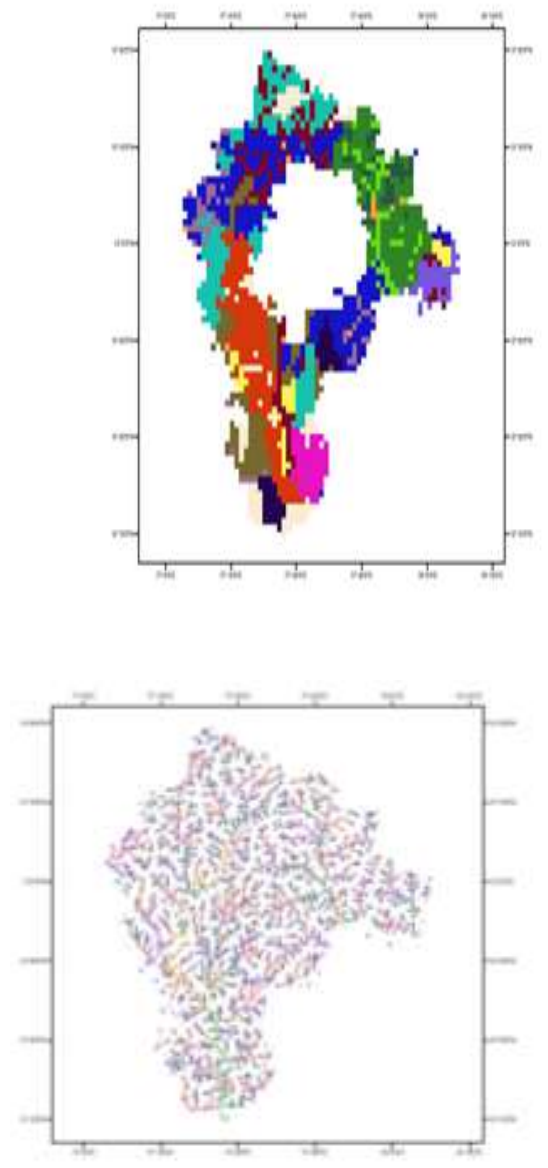

Legend
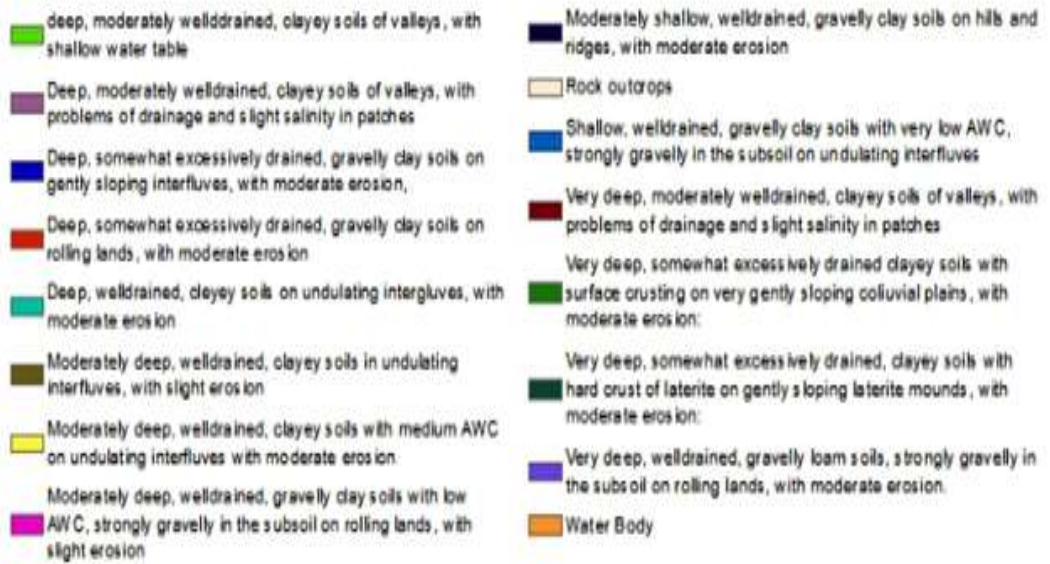

Figure 6: Soil Depth Parameters map

natural flow path for transportation of waste water from sewage treatment plants to the wastelands to enable an economical transportation line.

\section{Legend}

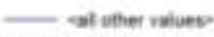

ORID_CODE

$-1$

$-2$

$\longrightarrow$

$-3$

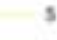

$\cdot$

Figure 7: Stream feature map

\section{V.WEIGHTED OVERLAY ANALYSIS}

For weighted overlay analysis LULC map, soil texture map, soil depth characteristics and slope maps are considered.

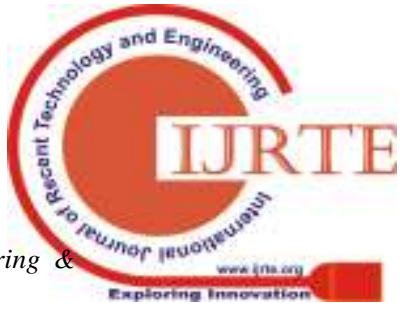




\section{DECENTRALIZED MANAGEMENT OF URBAN WASTEWATER FOR RURAL AGRICULTURAL UTILIZATION}

LULC and slope map are given higher weightages as they are features which cannot be altered whereas the soil texture and soil depth characteristics are given lower weightages as suitable alternative measures can be given, Different weightages assigned are summarized in Table 1.

Table 1: Weighted overlay analysis data overview

\begin{tabular}{|c|c|c|c|c|}
\hline Map & $\begin{array}{c}\% \\
\text { weight }\end{array}$ & Range & Feature Identity & Value \\
\hline \multirow{5}{*}{ LULC Map } & \multirow{5}{*}{35} & - & Cropland, Buildup area, water body & 1 \\
\hline & & - & Plantation & 2 \\
\hline & & - & Fallow Land & 3 \\
\hline & & - & Deciduous Forest, Mixed Forest & 4 \\
\hline & & - & Wetlands, Wasteland, Barrenland, Shurbland & 5 \\
\hline \multirow{5}{*}{ Soil Depth Characteristics } & \multirow{5}{*}{20} & - & Water body & 1 \\
\hline & & - & Shallow & 2 \\
\hline & & - & Very Deep & 3 \\
\hline & & - & Deep & 4 \\
\hline & & - & Moderately Deep & 5 \\
\hline \multirow{5}{*}{ Soil Texture Map } & \multirow{5}{*}{35} & $22-25$ & Rapidly drained & 1 \\
\hline & & $25-27$ & Well drained & 2 \\
\hline & & $27-29$ & Moderately drained & 3 \\
\hline & & $29-31$ & Poorly drained & 4 \\
\hline & & $31-36$ & Very Poorly drained & 5 \\
\hline \multirow{5}{*}{ Slope Map } & \multirow{5}{*}{10} & $0-4.54$ & Gently sloping & 5 \\
\hline & & $4.54-12.33$ & Moderately sloping & 4 \\
\hline & & $12.33-25.31$ & Moderately steep sloping & 3 \\
\hline & & $25.31-43.49$ & Steep sloping & 2 \\
\hline & & $\begin{array}{l}43.49- \\
165.51\end{array}$ & Precipitous sloping & 1 \\
\hline
\end{tabular}

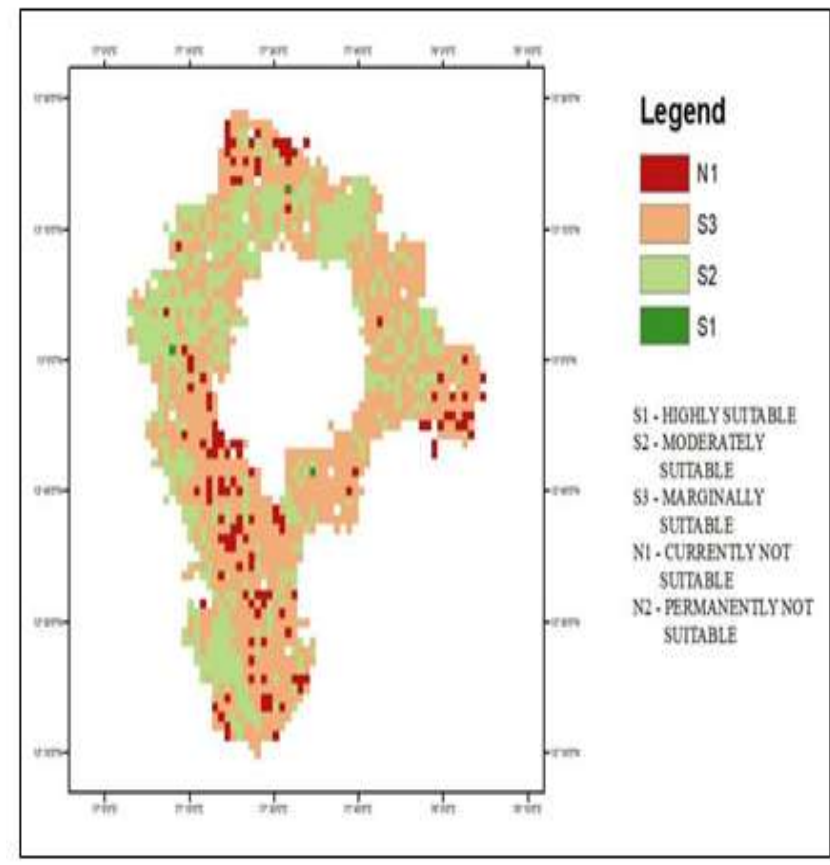

Figure 8: Output of weighted overlay analysis
There are 3 land suitability classes within the order 'suitable'- S and 2 land suitability classes under the order 'not suitable'- N. There are categorized as highly suitable $\mathrm{S} 1$, moderately suitable $\mathrm{S} 2$, marginally suitable $\mathrm{S} 3$, currently not suitable N1 and permanently not suitable as N2 (figure $8)$.

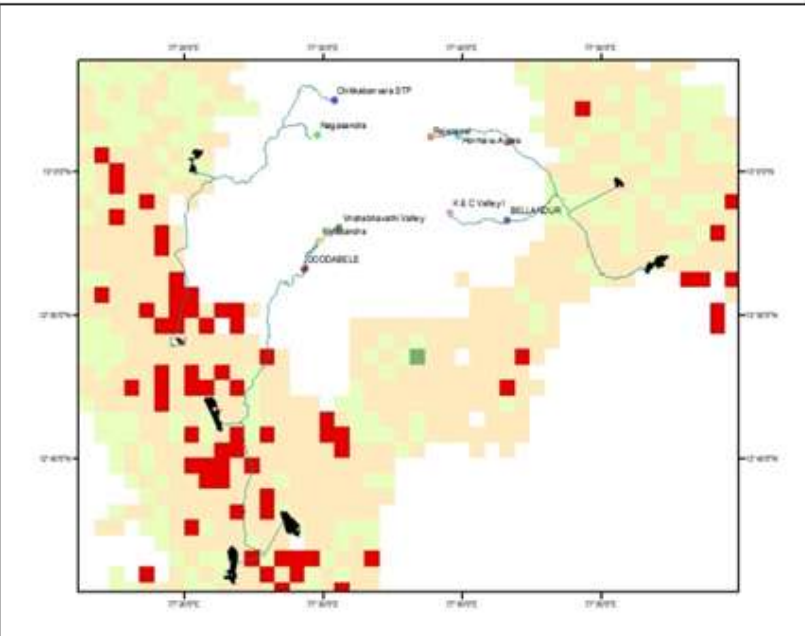

Figure 9: Identified optimal location of wasteland

\section{RESULT}

The weighted overlay analysis results, wastelands identified using LULC map and stream flow map all together is utilized to obtain optimal location of wasteland for each STP. 
The areas identified were strictly based on available wastelands and natural stream flow path from STP to wastelands and which are under the order 'suitable' from weighted overlay analysis (figure 9). Based on the water quality parameters (BOD of outlet from STP) area required for treatment is calculated for each STP (equation 1) and is compared with area of available wastelands to arrive at the final quantity of water that can be treated, as summarized in table 2 .

As the area of suitable wastelands are limited, the secondary treated water from STPs on the same streamline flow are directed to the same wasteland. However, the water from each STP should be addressed separately on the CWs. The quantity of water treated is decided based on the capacity of the CWs

and the proximity of the STP to the proposed location of CWs.

Proposal: Hence the treated water from Raja Canal, Horamavu Agara and Yellamapachetty STP are directed to the same waste land. The output from Horamavu Agara and Yellamapachetty STP are completely addressed at the CWs and fractional output from Raja Canal STP is addressed. The treated water from K C Valley and Bellandur STP are directed to the same waste land. The output from Bellandur STP are completely addressed at the CWs and fractional output from K C Valley STP is addressed.

In these proposed areas for constructed wetlands macrophytes like Salvinia Molesta (kariba weed, gaint salvinia), Hydrilla verticillata, Eichhornia Crassipes, Pistia Stratiotes, Spirodela Polyrhiza, Azolla Pinnata, Typha Angustifolia and Cyprus Alternifolius can be used for further treatment to remove heavy metals and total suspended solids (TSS) [5]. Few macrophytes are studied and proved to be efficient for removal of heavy metals which is summarized in the table 3 below.

Table 2: Area, capacity and distance calculations

\begin{tabular}{|c|c|c|c|c|c|c|c|c|}
\hline Sl. No & STP Location & $\begin{array}{c}\text { Outlet } \\
\text { in MLD }\end{array}$ & $\begin{array}{c}\text { BOD } \\
\text { influent } \\
(\mathrm{mg} / \mathrm{L})\end{array}$ & $\begin{array}{c}\text { BOD } \\
\text { effluent } \\
(\mathrm{mg} / \mathrm{L})\end{array}$ & $\begin{array}{c}\text { Area } \\
\text { required } \\
\text { in ha }\end{array}$ & $\begin{array}{c}\text { Waste land } \\
\text { Area in } \\
\text { hectares }\end{array}$ & $\begin{array}{c}\text { MLD of water } \\
\text { that can be } \\
\text { treated }\end{array}$ & $\begin{array}{c}\text { Distance } \\
\text { from STP To } \\
\text { CW (km) }\end{array}$ \\
\hline 1 & Raja canal & 40 & 11.62 & 1.66 & 77.84 & \multirow{3}{*}{105.38} & 19.17 & \multirow{3}{*}{32.238} \\
\hline 2 & Hormavu Agara & 20 & 8.99 & 1.29 & 38.9 & & 20 & \\
\hline 3 & Yellamapachetty & 15 & 5.51 & 0.79 & 29.17 & & 15 & \\
\hline 4 & K\&C Valley & 248 & 1.78 & 0.25 & 482.34 & \multirow{2}{*}{313.09} & 70 & \multirow{2}{*}{38.129} \\
\hline 5 & Bellandur & 90 & 7.91 & 1.13 & 175.04 & & 90 & \\
\hline 6 & Mylasandra & 75 & 7.4 & 1.06 & 145.87 & 469.92 & 75 & 58.812 \\
\hline 7 & Vrishabhavathi Valley & 110 & 67 & 9.57 & 213.94 & 474.62 & 110 & 60.104 \\
\hline 8 & Chikkabanavara & 5 & 20.85 & 2.98 & 9.72 & 215.38 & 5 & 30.107 \\
\hline 9 & Doddabele & 20 & 69.84 & 9.98 & 38.9 & 413.54 & 20 & 30.675 \\
\hline 10 & Nagasandra & 20 & 17.29 & 2.47 & 38.9 & 49.06 & 20 & 48.774 \\
\hline
\end{tabular}

Table 3: Metal removal efficiency of macrophytes

\begin{tabular}{|c|c|c|c|c|c|c|l|}
\hline Macrophyte & $\mathbf{C r}$ & $\mathbf{C u}$ & $\mathbf{Z n}$ & $\mathbf{C d}$ & $\mathbf{F e}$ & $\mathbf{N i}$ & \multicolumn{1}{|c|}{ Reference } \\
\hline Eichhornia Crassipes & $65 \%$ & $1 \%$ & $4 \%$ & & $19 \%$ & - & Lissy et al., 2011. \\
\hline Pistis Stratiotes & $81 \%$ & $96 \%$ & $90 \%$ & $78 \%$ & $87 \%$ & - & $\begin{array}{l}\text { Virendra Kumar Mishra and } \\
\text { B.D.Tripathi, 2008 }\end{array}$ \\
\hline Spirodila Polyrhiza & $83 \%$ & $91 \%$ & $90 \%$ & $63 \%$ & $83.50 \%$ & - & $\begin{array}{l}\text { Virendra Kumar Mishra and } \\
\text { B.D. Tripathi, 2008 }\end{array}$ \\
\hline Azolla Pinnata & - & $59.10 \%$ & $83 \%$ & $90 \%$ & $92.70 \%$ & $73.10 \%$ & Elsharawy et al., 2004 \\
\hline Typha Aungustifolia & $66.20 \%$ & $68 \%$ & $99.30 \%$ & - & - & $76.40 \%$ & Yadav A.K. et.al, 2012 \\
\hline Cyprus Alternifolius, & $68.40 \%$ & $72.70 \%$ & $93.17 \%$ & - & - & $83.60 \%$ & Yadav A.K. et.al, 2012 \\
\hline
\end{tabular}

\section{CONCLUSION}

The output of the study is the optimal location of wastelands for employment of CWs that supports tertiary treatment including removal of heavy metals. Using suitable conventional data and maps, thematic layers were prepared which were utilized for weighted overlay analysis. Weighted overlay analysis enabled integrating and mapping of thematic layers and determine land suitability by assigning weights and values to each layer and its parameters respectively. Using the secondary treated water quality parameters, quantitative study and calculations were performed to find the $\mathrm{CW}$ area that can be constructed using available area of wastelands. Also the suitable Macrophytes for checking TSS and for heavy metal removal were proposed.

\section{REFERENCES}

1. Swati Baliyan, Guru Prasad V, Tejaswini M and Jessen George, "Assessment of heavy metal contamination in tubers sold in local markets of Bangalore, Karnataka,

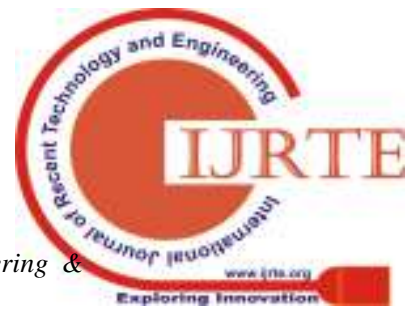




\section{DECENTRALIZED MANAGEMENT OF URBAN WASTEWATER FOR RURAL AGRICULTURAL UTILIZATION}

India", International research journal of environmental sciences, volume 7, pp 24-28, August 2018.

2. M.S.Nagaraja Gupta, C.Sadashivaiah, G.Ranganna, Inayathulla, H.Chandrashekar, "On Assessment of Heavy Metals in Water Sources of Peenya Industrial Area, Bengaluru, India", International Journal of Engineering Research \& Technology, special issue, 2015.

3. Shuh-Ren Jing, Ying-Feng Lin, Kai-Chung Shih, and Hung-Wei Lu, "Applications of Constructed Wetlands for Water Pollution Control in Taiwan: Review", IEEEPractice periodical of hazardous, toxic, and radioactive waste management, volume 14, pp. 249-259. 2008.

4. Ramachandra T.V, Sudarshan P Bhat., Vinay S "Constructed wetlands for tertiary treatment of wastewater", Energy and wetlands research group.IISC, 2017.

5. Sudarshan Bhat, Mahesh M K and Ramachandra T V, "Macrophytes of Bangalore Wetlands", ENVIS Technical Report 126, Energy \& Wetlands Research Group, CES, IISc, 2017.

6. D.Q. Zhang, S.K.Tan, "Decentralized Wastewater Management and its Application in an Urban Area of Beijing, China", 4th International Conference on Bioinformatics and Biomedical Engineering Chengdu, China, 18-20 June.

7. Kontoes et.al. "An experimental system for the integration of GIS data in knowledge-based image analysis for remote sensing of agriculture", International Geographical Information Systems, volume 7, no. 3, pp 247-262, 2007.

8. Leslie Miller-Robbie, Anu Ramaswami1, and Priyanie Amerasinghe, "Wastewater treatment and reuse in urban agriculture: exploring the food, energy, water, and health nexus in Hyderabad, India", volume 12, pp $73-84$, 2017.

9. María Fernanda Jaramillo ID and Inés Restrepo, "Wastewater Reuse in Agriculture: A Review about Its Limitations and Benefits" MDPI, 9 (15), pp 113 - 131, 2001.

10. Umer Mujtaba Khan and Nadeem Khalil, "Constructed Wetlands for Domestic Wastewater Treatment -A Promising Technology for Rural Areas in India", International Journal of Engineering Technology Science and Research, volume 4, issue 6, pp 398-404, 2017.

11. Gerrad David Jones and Bridget Marie Wadzuk, "Predicting Performance for Constructed Storm-Water Wetlands", journal of hydraulic engineering, pp 11581164, 2013.

12. T Y Yeh, "Removal of Metals in Constructed Wetlands: Review", IEEE Practice periodical of hazardous, toxic and radioactive waste management, pp 96-101, 2008.

13.Zongming Wang, et.al. "Remote Sensing of Spatial Distribution of Wetlands in North east China" 2016 IEEE 978-1-5090-3332-4/16/31.00.

14.X.T. Li, S. H., J.R. Li, M. Xu, "2007 IEEE International Geoscience and Remote Sensing Symposium”, pp. 112129. 2007.

15. BAI Mingchang "The Wetland Landscape Ecological Research Based on RS and GIS Technology", IEEE Workshop on Advanced Research and Technology in Industry Applications (WARTIA), 2014.

16. Lin. Zhua, Yanfang. Xiaoa, Lingling. Jinga, Yun. Chenc, Peng. Houb, Jian. Liana, "Evaluating Social Service Value of Wetlands in Beijing Based on Remote Sensing And GIS", IGARSS 2010, pp378-381, 2010.

17. Tomenko, S. Ahmed, V. Popova, "Modelling constructed wetland treatment system performance", Ecological Modelling, Elsevier, volume 205(3), pp 355-364, 2007.
18. S. L. Ozesmi and M. E. Bauer, "Satellite remote sensing of wetlands", Wetlands Ecology and Management, volume 10, pp 381-402, 2002.

19.R. T. Woodward, Y.S. Wui, "The economic value of wetland services: a meta-analysis", Ecological Economics 37, pp 257-270, 2000. 